\title{
First cytogenetic study of Cavernicola pilosa Barber, 1937 (Hemiptera, Triatominae)
}

\author{
E.S. Souza', K.C.C. Alevi' ${ }^{2}$ A.R. Ribeiro', M.B. Furtado ${ }^{3}$, N.C.B.V. Atzingen ${ }^{3}$, \\ M.T.V. Azeredo-Oliveira ${ }^{2}$ and J.A. Rosa ${ }^{1}$ \\ 'Laboratório de Parasitologia, Departamento de Ciências Biológicas, \\ Faculdade de Ciências Farmacêuticas, Universidade Estadual Paulista "Júlio de \\ Mesquita Filho", Araraquara, SP, Brasil \\ 2Laboratório de Biologia Celular, Departamento de Ciências Biológicas, \\ Instituto de Biociências, Letras e Ciências Exatas, \\ Universidade Estadual Paulista "Júlio de Mesquita Filho", \\ São José do Rio Preto, SP, Brasil \\ ${ }^{3}$ Fundação Casa da Cultura de Marabá, Marabá, PA, Brasil \\ Corresponding author: K.C.C. Alevi \\ E-mail: kaiochaboli@hotmail.com
}

Genet. Mol. Res. 14 (4): 13889-13893 (2015)

Received May 27, 2015

Accepted August 26, 2015

Published October 29, 2015

DOI http://dx.doi.org/10.4238/2015.October.29.9

ABSTRACT. Cavernicola pilosa is a triatomine species that lives in caves and feeds on bat blood. This vector has a wide geographical distribution, and is found in Brazil, Colombia, Panama, Peru, and Venezuela. Little is known about the reproductive biology of this species, because most previous studies have only characterized its morphology, morphometry, ecology, and epidemiology. Therefore, this study aimed to obtain preliminary data related to spermatogenesis in $C$. pilosa by conducting cytogenetic analysis. Analysis of the heterochromatic pattern of $C$. pilosa during the initial prophases revealed that heterochromatic blocks are only present in the sex chromosomes. Based on the analyses of the meiotic metaphase and prophases, we found that the sex determination system of C. pilosa is $\mathrm{XY}$ and the chromosomes are holocentric. C. pilosa spermatids are filamentous and have long flagella. It was not possible to detect corpuscle 
or filament heteropycnosis in spermatids of this species. The initial cytogenetic data presented in this study are important in characterizing the spermatogenesis and heterochromatic patterns of $C$. pilosa. Our results suggest that adaptation to troglodytism did not result in differences in spermatogenesis in this vector.

Key words: Tribe Cavernicolini; Spermatogenesis; Heterochromatin

\section{INTRODUCTION}

Triatomines are hematophagous vectors of the protozoan Trypanosoma cruzi, 1909 (Kinetoplastida, Trypanosomatidae), which is the etiological agent of Chagas disease. The Triatominae subfamily includes 148 species (Rosa et al., 2012; Abad-Franch et al., 2013; Alevi et al., 2013a; Gonçalves et al., 2013; Jurberg et al., 2013; Poinar Jr., 2013) that are distributed in 18 genera and six tribes (Galvão et al., 2003; Tartarotti et al., 2006; Alevi et al., 2013a).

The tribe Cavernicolini Usinger, 1944, is composed of only two species of the genus Cavernicola Barber, 1937, namely Cavernicola lenti Barrett \& Arias, 1985 and Cavernicola pilosa Barber, 1937. Both members of the Cavernicolini tribe (as the Cavernicola genus) were initially described from C. pilosa. Oliveira et al. (2007) redescribed the Cavernicolini tribe as the Cavernicola genus based on the morphological and morphometric characteristics of C. lenti and C. pilosa.

C. pilosa mainly inhabits caves, feeds on bat (Desmodus rotundus) blood (Lent and Wygodzinsky, 1979) and disperse passively in bat hair (Oliveira et al., 2008). This vector has a wide geographical distribution, and is found in Brazil (Bahia, Espírito Santo, Goiás, Minas Gerais, Mato Grosso do Sul, Mato Grosso, Pará, Paraná, and Tocantins), Colombia (Cundinamarca, Meta, Tolima, and Valle), Panama, Peru (Loreto), and Venezuela (Cojedes, Portuguesa, Táchira, Lara, and Amazonas) (Galvão et al., 2003; Gurguel-Gonçalves et al., 2012).

Little is known about the reproductive biology of this vector, because previous studies have only characterized its morphology and morphometry (Lent and Jurberg, 1969; Oliveira et al., 2007), ecology (Oliveira et al., 2008), and epidemiology (Dias et al., 1942; Baker et al., 1978; Silva et al., 1992). Therefore, this study aimed to obtain preliminary data concerning spermatogenesis in this species.

\section{MATERIAL AND METHODS}

Because of the difficulty in collecting and maintaining C. pilosa in insectariums, we only used one fifth-instar nymph that was collected in a cave in Marabá, PA, Brazil. This insect was dissected and its seminiferous tubules were placed in methanol:acetic acid (3:1). For slide preparation, each tubule was bathed twice in distilled water for $5 \mathrm{~min}$. The tubules were then placed in a $45 \%$ acetic acid solution for $10 \mathrm{~min}$, squashed, stained with lacto-aceto-orcein (De Vaio et al., 1985, with modifications by Alevi et al., 2012), and C-banding (Sumner, 1972). The slides were examined (total increase of 1000X) under a Jenaval light microscope (Zeiss, Jena, Germany), and images were captured using AxioVision LE 4.8 (Zeiss).

\section{RESULTS}

Polyploid nuclei were observed during all stages of spermatogenesis (Figure $1 \mathrm{~A}$ and $\mathrm{B}$ ). These cells exhibited one heterochromatic (Figure 1A) and one heteropycnotic corpuscle (Figure 
1B). By analyzing the meiotic prophases, it was possible to study the sex chromosomes, which were completely heterochromatic (Figure 2A) and heteropycnotic (Figure 2B). The sex determination system is probably XY. In addition, by analyzing the prophase, we discovered that there were no heterochromatic blocks in the autosomes (Figure $2 \mathrm{~A}$ ). Although it was not possible to ascertain the species karyotype by studying metaphase I (Figure 2C and D), we did find that the chromosomes are holocentric. We characterized the spermatids during spermiogenesis, which were completely filamentous with long flagella (Figure 2E).

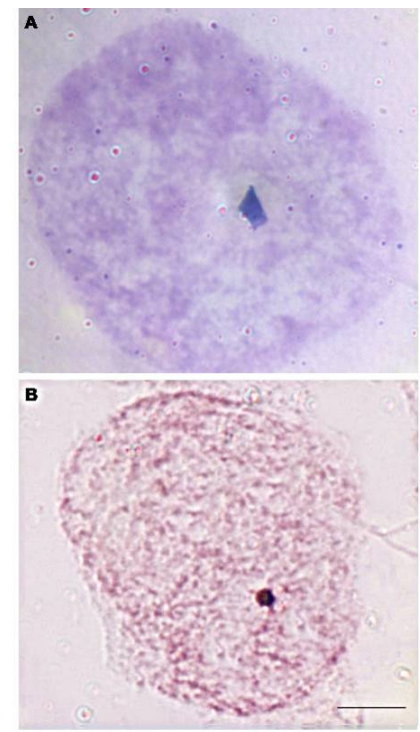

Figure 1. Polyploid nuclei of Cavernicola pilosa. Note the presence of a heterochromatic (A) and heteropycnotic corpuscle (B). Bar, $10 \mu \mathrm{m}$.
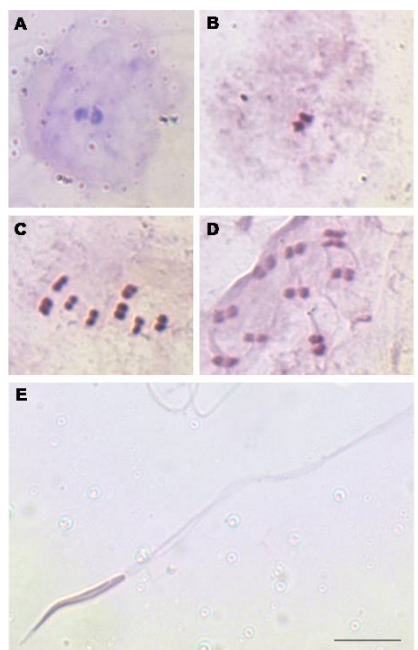

Figure 2. Spermatogenesis in Cavernicola pilosa. A. B. Initial prophase; the sex chromosomes were heterochromatic (A) and heteropycnotic (B). C. D. Metaphase I; note the holocentric nature of the chromosomes. E. Spermatid; note the filamentous form and the presence of a flagellum. Bar, $10 \mu \mathrm{m}$. 


\section{DISCUSSION}

Cytogenetic analyses of the Triatominae subfamily have been conducted for over 100 years (e.g., Payne, 1909), and is of utmost importance to detailed knowledge of cell biology, taxonomy, systematics, and evolution of the triatomines. The cytogenetic characterization of spermatogenesis in C. pilosa is important in understanding the reproductive biology and cytogenetics of this vector.

Polyploid nuclei are cells in seminiferous tubule walls that are responsible for cell nutrition during meiotic division. They exhibit high or low transcriptional activity, according to the requirement for reproduction (Alevi et al., 2013b). The absence of heterochromatic blocks in the PN suggests that there is no heterochromatin in C. pilosa autosomes, only in its sex chromosomes.

Analyzing the initial prophase to characterize this species is extremely important, because this phase of meiosis has been used as a cytotaxonomic tool for the study of the Triatoma maculata (Santos et al., 2007) and T. brasiliensis complexes (Alevi et al., 2014). Analyzing the heterochromatic pattern of $C$. pilosa during the initial prophases revealed that heterochromatic blocks are only present in the sex chromosomes.

The commonest sex determination system in the Triatominae is $X Y$. However, there are variations in the fragmentation of $X$, which results in $X_{1} X_{2} Y$ and $X_{1} X_{2} X_{3} Y$ (Ueshima, 1966; Alevi et al., 2013a). The sex determination system in C. pilosa is probably $X Y$, based on the meiotic metaphase and prophases.

The holocentric nature of triatomine chromosomes is characterized by the absence of a centromere, i.e., the kinetochore is dispersed throughout the chromosome (Hughes-Schrader and Schrader, 1961). By analyzing the metaphases, it was possible to characterize the chromosomes of $C$. pilosa as holocentric. However, it was not possible to describe the species karyotype.

Analysis of triatomine spermiogenesis has recently been used as a taxonomic tool to differentiate morphologically related species (Alevi et al., 2013c,d, 2014). C. pilosa spermatids were completely filamentous with long flagella. It was not possible to detect corpuscle or filament heteropycnosis in this species.

Although further cytogenetic studies should be conducted in C. pilosa, these initial cytogenetic data are important in characterizing the spermatogenesis and heterochromatic patterns of C. pilosa. Our results suggest that adaptation to troglodytism did not result in differences in spermatogenesis in this vector.

\section{Conflicts of interest}

The authors declare no conflict of interest.

\section{ACKNOWLEDGMENTS}

Research supported by Fundação de Amparo à Pesquisa do Estado de São Paulo (FAPESP), Conselho Nacional de Desenvolvimento Científico e Tecnológico (CNPq) and Coordenação de Aperfeiçoamento de Pessoal de Nível Superior (CAPES; Process \#23038.005 and \#285/2011-2012). 


\section{REFERENCES}

Abad-Franch F, Pavan MG, Jaramillo N, Palomeque FS, et al. (2013). Rhodnius barretti, a new species of Triatominae (Hemiptera: Reduviidae) from western Amazonia. Mem. Inst. Oswaldo Cruz 108: 92-99.

Alevi KCC, Mendonça PP, Pereira NP, Rosa JA, et al. (2012). Karyotype of Triatoma melanocephala Neiva and Pinto (1923). Does this species fit in the Brasiliensis subcomplex? Infect. Gen. Evol. 12: 1652-1653.

Alevi KCC, Rosa JA and Azeredo-Oliveira MTV (2013a). Mini review: karyotypic survey in Triatominae subfamily (Hemiptera, Heteroptera). Ent. Orn. Herp. 2: 106.

Alevi KCC, Mendonça PP, Pereira NP, Rosa JA, et al. (2013b). Análise das Regiões Organizadoras Nucleolares e da atividade nucleolar em Triatoma melanocephala e T. lenti, importantes vetores da doença de Chagas. Rev. Ciênc. Farm. Basica Apl. 34: 417-21.

Alevi KCC, Mendonça PP, Pereira NP, Fernandes ALVZ, et al. (2013c). Analysis of spermiogenesis like a tool in the study of the triatomines of the Brasiliensis subcomplex. C. R. Biol. 336: 46-50.

Alevi KCC, Mendonça PP, Pereira NP, Rosa JA, et al. (2013d). Heteropyknotic filament in spermatids of Triatoma melanocephala and T. vitticeps (Hemiptera, Triatominae). Inv. Rep. Dev. 58: 9-12.

Alevi KCC, Rosa JA and Azeredo-Oliveira MTV (2014). Cytotaxonomy of the Brasiliensis subcomplex and Triatoma brasiliensis complex (Hemiptera, Triatominae). Zootaxa 3838: 583-589.

Baker JR, Miles MA, Godfrey DG and Barrett TB (1978). Biochemical characterization of some species of Trypanosoma (Schizotrypanum) from bats (Microchiroptera). Am. J. Trop. Med. Hyg. 27: 483-491.

De Vaio ES, Grucci B, Castagnino AM, Franca ME, et al. (1985). Meiotic differences between three triatomine species (Hemiptera: Reduviidae). Genetica 67: 185-191.

Dias E, Mello GP, Costa O, Dasmaceno R, et al. (1942). Investigações sobre esquisotripanose de morcegos no Estado do Pará. Encontro do barbeiro "Cavernicola pilosa" como transmissor. Rev. Bras. Biol. 2: 103-110.

Galvão C, Carcavallo RU, Rocha DS and Jurberg J (2003). A checklist of the current valid species of the subfamily Triatominae Jeannel, 1919 (Hemiptera, Reduviidae) and their geographical distribution, with nomenclatural and taxonomic notes. Zootaxa 202: 1-36.

Gonçalves TCM, Teves-Neves SC, Santos-Mallet JR, Carbajal-de-la-Fuente AL, et al. (2013). Triatoma jatai sp. nov. in the state of Tocantins, Brazil (Hemiptera: Reduviidae: Triatominae). Mem. Inst. Oswaldo Cruz 108: 429-437.

Gurgel-Gonçalves R, Galvão C, Costa J and Peterson AT (2012). Geographic distribution of Chagas disease vectors in Brazil based on ecological niche modeling. J. Trop. Med. 2012: 1-15.

Hughes-Schrader S and Schrader F (1961). The kinetochore of Hemiptera. Chromosoma 12: 327-350.

Jurberg J, Cunha V, Cailleaux S, Raigorodschi R, et al. (2013). Triatoma pintodiasi sp. nov. do subcomplexo T. rubrobaria (Hemiptera, Reduviidae, Triatominae). Rev. Pan-Amaz. Saúde 4: 43-56.

Lent $\mathrm{H}$ and Jurberg J (1969). O gênero Cavernicola Barber, 1937, com um estudo sobre a genitália externa (Hemiptera, Reduviidae, Triatominae). Rev. Bras. Biol. 29: 317-327.

Lent $\mathrm{H}$ and Wygodzinsky P (1979). Revision of the Triatominae (Hemiptera, Reduviidae), and their significance as vectors of Chagas. Bull. Am. Mus. Nat. Hist. 163: 123-520.

Oliveira MA, Souza RCM and Diotaiuti L (2007). Redescription of the genus Cavernicola and the tribe Cavernicolini (Hemiptera: Reduviidae: Triatominae), with morphological and morphometric parameters. Zootaxa 1457: 57-68.

Oliveira MA, Ferreira RL, Carneiro MA and Diotaiuti L (2008). Ecology of Cavernicola pilosa Barber, 1937 (Hemiptera: Reduviidae: Triatominae) in the Boa Esperança Cave, Tocantins, Brazil. Biotropica 14: 63-68.

Payne F (1909). Some new types of chromosome distribution and their relation to sex. Biol. Bull. 16: 119-166.

Poinar Jr G (2013). Panstrongylus hispaniolae sp. n. (Hemiptera: Reduviidae: Triatominae), a new fossil triatomine in Dominican amber, with evidence of gut flagellates. Palaeodiversity 6: 1-8.

Rosa JA, Rocha CS, Gardim S, Pinto MC, et al. (2012). Description of Rhodnius montenegrensis n. sp. (Hemiptera, Reduviidae: Triatominae) from the state of Rondônia, Brazil. Zootaxa 3478: 62-76.

Santos SM, Lopes CM, Dujardin JP, Panzera F, et al. (2007). Evolutionary relationships based on genetic and phenetic characters between Triatoma maculata, Triatoma pseudomaculata and morphologically related species (Reduviidae: Triatominae). Infec. Genet. Evol. 7: 469-475.

Silva IG, Silva HHG and Elias M (1992). Invasão de Cavernicola pilosa Barber, 1937 (Hemiptera, Reduviidae) em habitação humana na periferia de Goiânia. Rev. Patol. Trop. 21: 263-264.

Sumner AT (1972). A simple technique for demonstrating centromeric heterochromatin. Exp. Cell Res. 75: 305-306.

Tartarotti E, Azeredo-Oliveira MTV and Ceron CR (2006). Phylogenetic approach to the study of triatomines (Triatominae, Heteroptera). Braz. J. Biol. 66: 703-708.

Ueshima N (1966). Cytotaxonomy of the triatominae (Reduviidae: Hemiptera). Chromosoma 18: 97-122. 